Article

\title{
The Assessment of Historic Towns' Outstanding Universal Value Based on the Interchange of Human Values They Exhibit
}

\author{
Ayman Abdel Tawab \\ Department of Architectural Engineering, Tanta University, Tanta 31511, Egypt; a_g_a_abdeltawab@yahoo.co.uk; \\ Tel.: +2-010-2301-8833 \\ Received: 4 May 2019; Accepted: 8 July 2019; Published: 10 July 2019

\begin{abstract}
Influences exerted by cultural heritage properties on developments in architecture, town planning, or landscape design represent one of the criteria that are used to evaluate the Outstanding Universal Value of the properties nominated for listing as World Heritage Sites, which is criterion (ii). In 1996, the wording of criterion (ii) was revised to address the interchange of human values exhibited by cultural heritage properties. The main aim of this study was to discuss the changes that occurred to the application of criterion (ii) following the revision of its wording of 1996, particularly in relation to historic towns. The study also aimed at investigating the applicability of the revised version of criterion (ii) to the particularity of the cultural heritage of an Egyptian historic town and a potential World Heritage Site, which is "Historic quarters and monuments of Rosetta/Rachid". To achieve these aims, a sample of World Heritage Sites, or potential ones, representing both the pre-1996 and the post-1996 historic towns whose Outstanding Universal Value was justified based on criterion (ii), was adopted for the analysis of the changes in the application of criterion (ii). Subsequently, a brief preview of the major features that represent the mutual influences experienced throughout Rosetta's wider cultural context was carried out. The findings revealed that the prevalent trend in the post-1996 listings of historic towns is the emphasis on other cultures' influences exerted on the concerned historic towns through interchanges of human values that take the form of exchanges of technical know-how, traditions and religious values. The findings also indicated the applicability of the revised version of criterion (ii) to the particularity of Rosetta's cultural heritage. The study recommends inscribing Rosetta on the World Heritage List based on criterion (ii).
\end{abstract}

Keywords: historic towns; World Heritage Sites; world heritage criteria; Outstanding Universal Value; Rosetta

\section{Introduction}

Adopted by the UNESCO in 1972, the World Heritage Convention established the concept of listing heritage assets that enjoy internationally acknowledged heritage significance as World Heritage Sites (WHSs). The convention refers to this international level of significance as an Outstanding Universal Value (OUV) and associates it with the heritage properties that are important for all the peoples of the world and that are considered as heritage of mankind as a whole [1]. Subsequently, a supplementary document to the convention was adopted in 1977 to explain the various subjects associated with the management of WHSs, which is the "Operational Guidelines for the Implementation of the World Heritage Convention" (OGs) and which was revised several times later. The OGs adopted a list of six criteria that should be used to evaluate whether the properties nominated for listing as cultural WHSs enjoy an OUV or not, and another list of four criteria pertinent to natural heritage. The second criterion, criterion (ii), of the cultural heritage list indicated that each nominated cultural property should have exerted considerable influences on developments in architecture, landscape design, or human 
settlements [2] so that the nominated property could be considered to enjoy an OUV. Since 1977, the OGs have been revised several times. The OGs' version of 1996 involved an amendment of the wording of criterion (ii). According to this amendment, criterion (ii) would be concerned with cultural heritage properties that exhibit an interchange of human values on developments in architecture or town planning [3] instead of the previous interest in the influences exerted on other properties.

Historic towns represent a well-established type of cultural WHSs. Only one Egyptian historic town is inscribed as a WHS, which is "Historic Cairo". However, the Egyptian Tentative List, of potential WHSs, still involves another property representing historic towns, which is "Historic quarters and monuments of Rosetta/Rachid" [4]. The criteria that were adopted to justify Rosetta's potential OUV involve criterion (ii) [5].

The amendment carried out to the wording of criterion (ii) indicates the acknowledgement of the significance of the mutual influences exerted between the concerned historic town and other relevant heritage properties, provided that these influences are the outcomes of interchanges of human values. The application of criterion (ii) in relation to historic towns is expected to be influenced by the amendment in its wording. Consequently, the study aimed at exploring the changes that occurred to the application of criterion (ii) following its amendment, particularly in relation to historic towns. The other objective of this study was to examine the validity of the hypothesis that this amendment further emphasizes the applicability of criterion (ii) to the particularity of Rosetta's cultural heritage and increases its chance in being inscribed on the World Heritage List (WHL) based on criterion (ii). A brief exploration of the characteristics of Rosetta's cultural heritage confirmed the validity of the previous hypothesis and revealed that Rosetta's cultural heritage was the subject of several influences exerted by the heritage of other properties abroad, and also played a major role in the development of a unique architectural style characteristic of the Delta region in Egypt.

\section{Theoretical Backgrounds}

\subsection{Significance of Heritage Assets}

The significance of a heritage asset can be defined as the summation of all the heritage values it enjoys, which make it of interest to the society [6]. The Burra Charter, which is the major ICOMOS charter concerned with the concept of the significance of heritage properties, provides a similar definition that describes cultural significance as an "aesthetic, historic, scientific, social or spiritual value" [7] (p. 2). The significance of heritage assets can be evaluated by a process that involves two stages; the first of which is concerned with understanding the characteristics and the historic development of the heritage asset, while the second is concerned with concluding the extent of appreciation of its values [6].

Evaluating the significance of heritage assets involves the identification of these assets' level of significance, which is usually expressed by what is referred to as "thresholds of heritage significance". These thresholds involve the personal threshold, the local threshold, the regional threshold, the national threshold, and the international threshold [8]. One of the significant hierarchical systems of heritage significance thresholds is referred to as Kerr's hierarchical system. According to this hierarchical system, thresholds of heritage significance increase from "no significance", to "unknown significance", to "limited significance", to "some significance", to "considerable significance", to "exceptional significance" [6]. Thresholds of heritage significance involve another threshold that is usually referred to as "negative significance" and is usually assigned to the elements in the heritage property that detract from its overall significance [6]. Aplin [9] suggests another hierarchical system of heritage significance that involves three dimensions concerned with establishing the significance of heritage assets; which are scale, importance, and either uniqueness or representativeness. The scale dimension comprises the various thresholds of heritage significance that involve the local, regional, state, national, and global thresholds [9]. 
The significance of a heritage asset can be evaluated by other measures that address particular qualities of the heritage asset, such as the rarity of the heritage asset, its condition and intactness, the survival of the heritage asset's context, the extent of the heritage asset's threats, and its age [10]. The overall significance of heritage properties can be evaluated by another relevant method that is based on comparison and on evaluating what can be described as the relative significance. According to this method, the significance of a heritage property is evaluated based on comparative criteria that involve, for instance, being the most complete example of a particular type of heritage properties, being the most representative example of its type, and being a good example of a particular architectural style. The relative significance of a heritage property can be evaluated using another list of criteria, which is referred to as Kerr's list, and based on the extent this property represents within a given context. These criteria involve, for instance, the age of the heritage property, the rarity of the property as an example of a particular type, the vulnerability of the property, the completeness and representativeness of the property, and the influences the property had on the emergence of new ideas and particular architectural movements [6].

Evaluating the significance of heritage properties should involve the identification of the heritage values that these properties enjoy, the evaluation of these properties' importance in comparison with other relevant properties, the identification of the elements that contribute to these properties' overall significance, and the evaluation of the relative significance of the various elements of these properties [6]. The evaluation should also involve the identification of these properties' stakeholders, who mainly involve the owners and the occupants of these properties and the other members of the local community who are associated with them [6]. Stakeholders of heritage properties represent a major source used to identify these properties' heritage values [11]. Therefore, evaluating the significance of heritage properties should also involve the documentation of the memories of the members of the local communities who are associated with these properties, and all their stakeholders [6].

The significance of heritage properties might change over time and with use [6,7]. The Burra Charter emphasizes that understanding cultural significance might change as a result of achieving new information on the concerned heritage place [7]. The charter emphasizes that the significance of heritage places can be influenced by the quality of the conservation interventions carried out to these places, and that the aim of these interventions should be to retain these places' significance. The charter also emphasizes that changes carried out to heritage places may be necessary to retain their significance, yet these changes are usually undesirable when they reduce these places' significance [7].

\subsection{Outstanding Universal Value of World Heritage Sites}

In 1972, the UNESCO adopted the World Heritage Convention, which is concerned with the conservation of the cultural and natural heritage properties that are significant to all the peoples of the world [1]. This convention was responsible for the introduction of a new threshold of heritage significance that is associated with these heritage properties. The convention and its OGs refer to this threshold as "Outstanding Universal Value" (OUV) [12], and describe it as the level of heritage significance that the cultural and natural heritage properties, which have exceptional qualities, enjoy, and which deserve special protection against the dangers that threaten them [13]. The OUV threshold is sometimes referred to as the 'world heritage value'. The notion of OUV may be interpreted to incorporate both uniqueness and representativeness, and may also be interpreted to imply that the concerned heritage property is the best of its kind [13]. Heritage resources can be considered to enjoy a universal value as long as they represent a true and authentic expression of a particular culture, whereas the adjective outstanding in the term OUV can be understood to pertain mainly to the best and/or the most representative example or examples of a type of heritage properties [14]. 
Properties nominated for listing as WHSs can be considered to enjoy an OUV if they were found to meet at least one of the 10 world heritage criteria; and should also successfully satisfy the conditions of authenticity and integrity and be proven to have adequate long-term legislative, regulatory, institutional, and/or traditional protection and management systems. The first six criteria of this list are concerned with cultural heritage, while the other four are concerned with natural heritage [12]. The first version of the OGs, which is that of 1977, cited the earliest text of the second criterion, criterion (ii), which stated that each property nominated for listing as a WHS should "have exerted considerable influence, over a span of time or within a cultural area of the world, on subsequent developments in architecture, monumental sculpture, garden and landscape design, related arts, or human settlements" [2] (p. 3). Since 1977, the OGs have been revised several times. The wording of criterion (ii) was revised in the OGs of 1996 to state that each property nominated for listing as a WHS should "exhibit an important interchange of human values, over a span of time or within a cultural area of the world, on developments in architecture or technology, monumental arts, town-planning or landscape design" [3] (p. 7), so that it can be inscribed on the WHL. The revised version of criterion (ii) of the OGs of 1996 remained unchanged in the latest version of the OGs, which is that of 2017 [12]. The amendment carried out to the wording of criterion (ii) in the OGs of 1996 indicates a shift in interest from influences exerted merely by the concerned heritage property on other properties to an interest in mutual influences exerted between the concerned property and other relevant properties, provided that these mutual influences take place through interchanges of human values. In both cases, the pre-1996 version of criterion (ii) and the post-1996 version, these influences might occur on two levels. The first is a temporal level, which is represented by a span of time over which the influences take place. The second is a geographical level, where the influences take place within a cultural area of the world.

Jokilehto [15] points out that the reasons for the amendment of the wording of criterion (ii) are not clear, even though they can be understood to be attributed to the interest in the nomination and listing of particular new types of cultural heritage, which involve mainly cultural landscapes and living cultures. The reasons seem also to be associated with earlier arguments on flaws in the representativeness of the WHL. The WHL was found to suffer from representational gaps represented by the over-representativity of particular heritage types and the heritage of particular UNESCO regions against an under-representativity of other heritage types and the heritage of other UNESCO regions. Among the under-represented types are vernacular heritage and traditional living communities' heritage [16], both of which are closely related to the two types of cultural heritage that Jokilehto [15] addresses, which are cultural landscapes and living cultures. To resolve these gaps, the World Heritage Committee adopted a strategy that is officially known as the Global Strategy in 1994 [16]. The time when the Global Strategy was adopted indicates a potential relationship with the amendment of the wording of criterion (ii) of 1996. Regarding that the OGs of 1996, which embraced the amendment of criterion (ii), represent the first version of the guidelines that were published following the adoption of the Global Strategy. What supports this conclusion is the particularity of the vernacular heritage of traditional living communities, who were a central subject in the arguments on the Global Strategy and the reasons put forward by Jokilehto [15]. Traditional living communities' vernacular heritage has always been characterized by its richness of evidences of mutual influences mainly exerted by the diverse cultures that these communities encountered during their long history. Taos Pueblo in the United States is an example of the traditional living communities whose vernacular heritage comprises various architectural paradigms that emphasize these mutual influences. An example of these paradigms is the external ovens, known as "hornos", in Taos Pueblo's earthen houses [17]. 
The justifications of the OUV of the WHSs inscribed based on criterion (ii) can be grouped under four themes. These themes involve "expressions of society"; "creative responses and continuity", which is concerned mainly with aspects like architecture; "spiritual responses", which is concerned with religions; and "movement of peoples". The first theme, "expressions of society", involves two subsidiary themes that are concerned with developing knowledge and communication, while the second theme, "creative responses and continuity", involves other subsidiary themes that are concerned with, for instance, religious and commemorative architecture, cultural landscapes and parks, urban settlements and transport structures, and 19th and 20th centuries urban settlements [15]. Among the examples of the first theme, "expressions of society", is the "Struve Geodetic Arc" WHS, which represents the new notion of the interchange of human values. The justifications of this WHS's OUV based on criterion (ii) suggest that this property is an exceptional example of interchange of human values in the form of cooperation among scientists from diverse countries. Consequently, this example can be classified under the subsidiary group concerned with development of knowledge. Among the examples of the second theme, "creative responses and continuity", is the "Naval Port of Karlskrona" WHS. The justifications of this property's OUV based on criterion (ii) indicate that the property incorporates elements derived from other properties in other countries, and that the concerned property became a model that inspired other subsequent towns [15], indicating the existence of mutual influences. These two examples represent the response to the amendment carried out to the wording of criterion (ii) in 1996.

\subsection{Major Classifications of Historic Towns}

There are three groups of historic towns, which involve the historic towns that are no longer inhabited, the historic towns that are still inhabited, and the new towns of the 20th century [12] (p. 82). "Mdina (Citta' Vecchia)" is a Maltese potential WHS and an example of the historic towns that are no longer inhabited, while "Historic Cairo" WHS in Egypt is an example of the historic towns that are still inhabited. Finally, "Brasilia" WHS in the Brazil is an example of the new towns of the 20th century [4].

The second group of the historic towns that are still inhabited involves four subsidiary groups; which are the historic towns that are typical of a specific period, the historic towns that have evolved along characteristic lines, the historic centers that cover exactly the same area as ancient towns and are enclosed within modern cities, and the sectors and areas or isolated units that provide evidence of the character of a historic town that has disappeared [12] (p. 83). "Historic quarters and monuments of Rosetta/Rachid", an Egyptian potential WHS, can be classified under the subsidiary group of the historic towns that are typical of a specific period because most of the remaining antiquities in the property belong to the Ottoman era [4]. The historic town in Rosetta can also be classified under the last subsidiary group that involves sectors and areas or isolated units because the remaining Islamic antiquities in Rosetta are scattered throughout its urban fabrics.

\section{Aim, Materials, and Method of the Study}

The main aim of this study was to discuss the changes that occurred to the application of world heritage criterion (ii) following the amendment carried out to its wording in 1996, particularly in relation to historic towns. The study also aimed at investigating the applicability of the revised version of criterion (ii) to the particularity of the cultural heritage of an Egyptian historic town and a potential WHS, which is "Historic quarters and monuments of Rosetta/Rachid". To analyze the changes that occurred to the application of criterion (ii), a sample of 11 case studies was adopted. This sample involves WHSs, or potential ones, representing the pre-1996 and the post-1996 historic towns. These case studies were chosen so that they represent WHSs whose OUV is justified based on criterion (ii). Six of these case studies represent the pre-1996 historic towns, while the other five represent the post-1996 historic towns. The pre-1996 case studies involve "Medina of Marrakesh" in Morocco, "Kairouan" in Tunisia, "Historic Centre of Cordoba" in Spain, "Historic City of Toledo" in Spain, "Medina of Fez" in Morocco, and "Medina of Tunis" in Tunisia. The post-1996 case studies involve 
"Mdina (Citta' Vecchia)" in Malta, "Historic Centre (Old Town) of Tallinn" in Estonia, "Historic Jeddah, the Gate to Makkah" in Saudi Arabia, "Le Havre, the City Rebuilt by Auguste Perret" in France, and the "White City of Tel-Aviv-the Modern Movement" in Israel.

The case studies were also selected so that they represent the various classifications of historic towns. Historic towns that are no longer inhabited are represented by the case study "Mdina (Citta' Vecchia)", while the new towns of the 20th century are represented by two case studies, which are "Le Havre, the City Rebuilt by Auguste Perret" and the "White City of Tel-Aviv-the Modern Movement". Finally, the historic towns that are still inhabited are represented by the other eight case studies. The case studies were also selected so that they represent other relevant themes. Most of the case studies were selected so that they represent the most relevant theme to Rosetta, which involves the medieval Islamic historic towns in northern Africa and other similar case studies in southern Europe. The other relevant theme is the theme that involves the historic towns of the Hanseatic League in northern Europe. The only case study that represents this theme is "Historic Centre (Old Town) of Tallinn".

Following the selection of the sample of case studies, the justifications of these historic towns' OUV based on criterion (ii), as discussed in their nomination documents or in the ICOMOS' reports, were analyzed. The aim of this analysis was to reveal the major themes and architectural paradigms that represent the exerted influences or the interchange of human values that these historic towns experienced. The analysis also aimed at revealing the major subsidiary trends of the application of criterion (ii) in the two groups of case studies, the pre-1996 and the post-1996 historic towns. Subsequently, the association between the application of criterion (ii) and the application of criterion (i) in the two groups of the pre-1996 and the post-1996 case studies was examined. Regarding that criterion (i) is another world heritage criterion that is concerned with the cultural WHSs that "represent a masterpiece of human creative genius" [12] (p. 25). The analysis of the changes in the application of criterion (ii) was followed by a brief preview of the major architectural features that represent the mutual influences exerted between Rosetta's cultural heritage and its wider cultural context and the interchange of human values through which these influences took place.

The study had some limitations, particularly in relation to the justifications of the OUV of one of the over-represented types of cultural heritage, which involves historic towns. The interest in inscribing more historic towns, such as Rosetta in Egypt, seems to contradict with the prerequisites of the Global Strategy for a balanced and diversified WHL. However, the heritage of Egypt and the two UNESCO's regions, which are the Arab States and Africa, is still under-represented on the WHL. Moreover, historic towns still represent an under-represented type of WHSs in Egypt and the Arab States region. Furthermore, the materials of the empirical study in connection with the analysis of the changes that occurred to the application of criterion (ii) in relation to the post-1996 historic towns were limited to the nomination documents and the ICOMOS reports of the adopted case studies. Interviews with the officials concerned with the management of WHSs of the adopted case studies were excluded. The reason is the diversity of the case studies and the broad geographical extent that incorporates them.

\section{Findings and Discussion}

\subsection{Changes in the Application of Criterion (ii) Following the Amendment of 1996}

The findings (Table 1) [18-26] indicated that the application of criterion (ii) in relation to the pre-1996 case studies is characterized by the existence of two major trends. The first trend is characterized by the influences that the concerned historic towns exerted on other relevant properties. The second trend is characterized by the influences exerted by other relevant properties that the concerned historic towns underwent. The findings (Table 1) revealed that the prevalent trend of the application of criterion (ii) in relation to the pre-1996 case studies is the first trend characterized by the focus on the influences exerted by the concerned historic towns on other relevant properties. However, there are few exceptions to this finding where the concerned historic towns acknowledged the influences they 
underwent, which were exerted by other relevant properties. These exceptions represent the second trend. Only two case studies represent the second trend, which are "Medina of Fez" and "Medina of Tunis". The justifications of the OUV of "Medina of Fez" based on criterion (ii) emphasize that the plan and design of the district known as "Fez Jadid" in the property were inspired by the earlier town plan of "Medina of Marrakesh" [20]. In relation to the second case study, "Medina of Tunis", the justifications of its OUV based on criterion (ii) emphasize the mutual influences, in the field of art and architecture, experienced throughout the property's wider context; which involves the Maghreb, southern Europe, and the Middle-East over many centuries [21].

Table 1. Analysis of the major themes and architectural paradigms addressed by the various justifications of the OUV based on criterion (ii) of the adopted pre-1996 case studies of historic towns (source: [18] (p. 3); [19] (p. 2); [20] (pp. 1-2); [21] (pp. 1-2); [22] (pp. 1-2); [23] (pp. 1-2); [24] (pp. 1-3); [25] (p. 1); [26] (p. 4)).

\begin{tabular}{|c|c|c|c|c|}
\hline & $\begin{array}{l}\text { Property } \\
\text { (State Party) }\end{array}$ & $\begin{array}{l}\text { Date of } \\
\text { Listing }\end{array}$ & Criteria & $\begin{array}{l}\text { Major Themes, and Architectural Paradigms that Represent the } \\
\text { Exerted Influences or Interchange of Human Values }\end{array}$ \\
\hline 1 & $\begin{array}{l}\text { Medina of } \\
\text { Marrakesh } \\
\text { (Morocco) }\end{array}$ & 1985 & (i), (ii), (iv), (v) & $\begin{array}{l}\text {-Influences by Marrakesh that remained a political, economic, and } \\
\text { cultural center for a long period; which were felt throughout the } \\
\text { western Muslim world from Northern Africa to Australia; } \\
\text {-Influences exerted by the earlier urban model of Marrakesh over } \\
\text { the development of Fez Jadid, an integral part of the Medina of Fez, } \\
\text { which was inscribed in } 1981 \text { on the WHL }\end{array}$ \\
\hline 3 & $\begin{array}{l}\text { Historic Centre of } \\
\text { Cordoba (Spain) }\end{array}$ & 1984,1994 & (i), (ii), (iii), (iv) & $\begin{array}{l}\text {-A considerable influence exerted by the mosque of Cordoba, } \\
\text { despite its uniqueness, on western Muslim art from the 8th century; } \\
\text {-Influences exerted on the development of "Neo-Mosque" styles of } \\
\text { the 19th century; } \\
\text {-Influences on both the Arabic and Christian cultures alike since the } \\
\text { 8th century by the building techniques that have been } \\
\text { experimented in the Great Mosque of Cordoba; } \\
\text {-Influences on all Spanish architecture by the architecture of the } \\
\text { Great Mosque of Cordoba, characterized by its architectural hybrid } \\
\text { that joins together many of the artistic values of the East and the } \\
\text { West and includes elements hitherto unheard-of in Islamic religious } \\
\text { architecture including the use of double arches to support the roof } \\
\text { and the "honeycomb" capital that is different from the Corinthian } \\
\text { capital characteristic of the caliph art }\end{array}$ \\
\hline 4 & $\begin{array}{l}\text { Historic City of } \\
\text { Toledo (Spain) }\end{array}$ & 1986 & (i), (ii), (iii), (iv) & $\begin{array}{l}\text {-Influences exerted by Toledo both during the Visigothic period, } \\
\text { when it was the capital of a kingdom that stretched all the way to } \\
\text { the Narbonnese region, and during the Renaissance when it became } \\
\text { one of the most important artistic centers in Spain }\end{array}$ \\
\hline & Subsidiary Trend tha & Case Studie: & 2, 3, 4 Represent & Influences Exerted by the Concerned Historic Town \\
\hline 6 & $\begin{array}{l}\text { Medina of Tunis } \\
\quad \text { (Tunisia) }\end{array}$ & 1979 & (ii), (iii), (v) & $\begin{array}{l}\text {-Exchanges of influences in the field of arts and architecture over } \\
\text { many centuries; which were encouraged by the early role played by } \\
\text { the Medina of Tunis between the Maghreb, Southern Europe, and } \\
\text { the East; } \\
\text {-Considerable influence on the development of architecture, } \\
\text { sculpture, related arts, and human settlements }\end{array}$ \\
\hline \multicolumn{4}{|c|}{ The Subsidiary Trend that the Case Studies 5, 6 Represent } & Influences Exerted on the Concerned Historic Town \\
\hline
\end{tabular}


The findings (Table 2) [27-33] indicated that the application of criterion (ii) in relation to the post-1996 case-studies is characterized by the existence of four major trends. The first trend is characterized by the influences exerted by other properties that the concerned historic towns underwent. The second trend is characterized by the existence of mutual and continuous influences experienced among the concerned historic towns and other relevant properties. The third trend is characterized by the existence of mutual influences experienced among the concerned historic towns and other relevant properties, provided that these mutual influences took place through interchanges of human values. Finally, the fourth trend is characterized by the integration of modern trends in architecture and town planning within the concerned historic towns' design and planning and is characterized also by seeking the influences exerted by modern architectural and town planning theories instead of the influences exerted by other properties.

Table 2. Analysis of the major themes and architectural paradigms addressed by the various justifications of the OUV based on criterion (ii) of the adopted post-1996 case studies of historic towns (source: [27] (pp. 89-90); [28] (pp. 1-2); [29] (p. 1); [30] (p. 1); [31] (pp. 1-2); [32] (pp. 1-2); [33] (p. 7)).

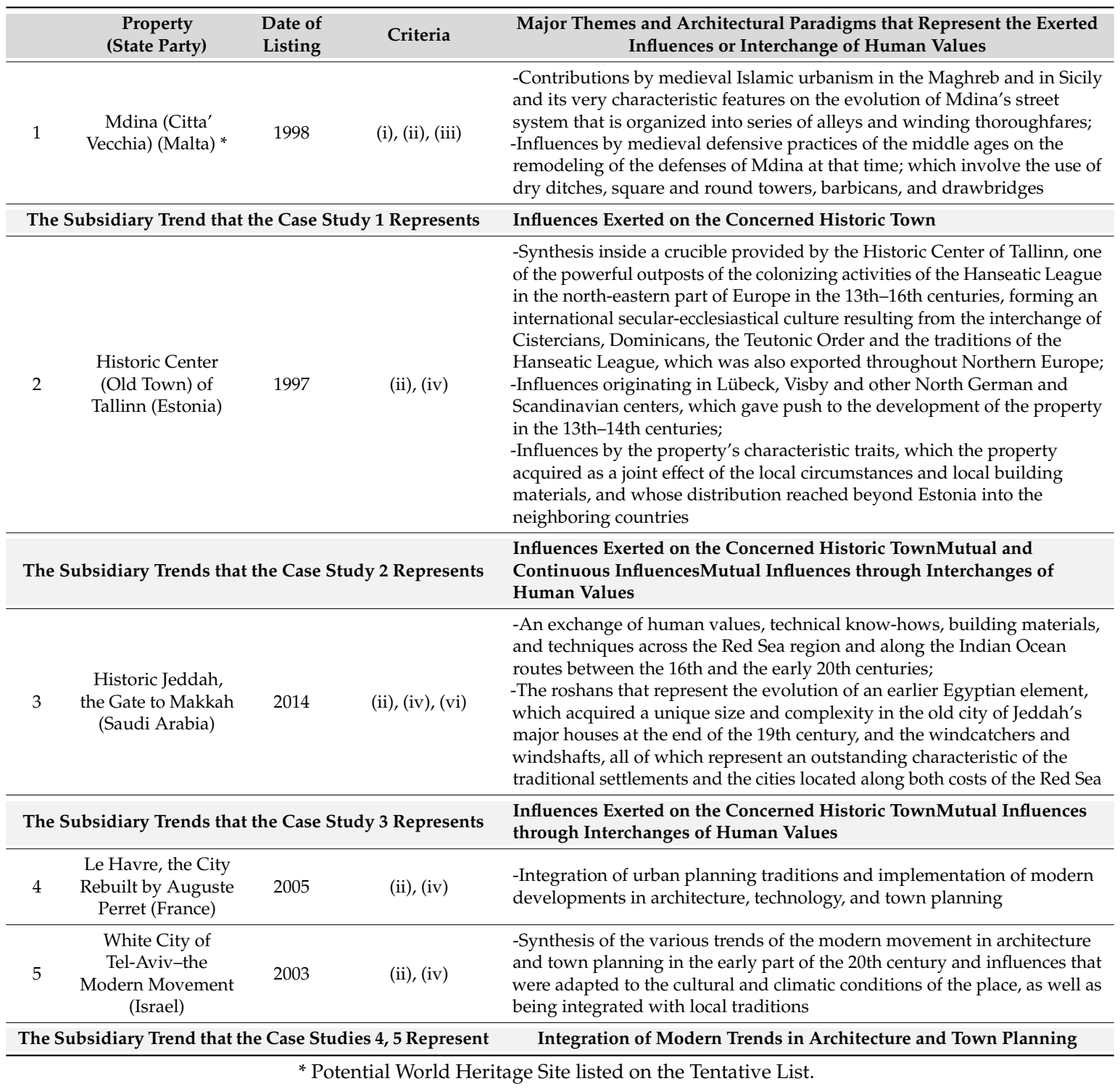


The findings (Table 2) showed that the major prevalent trend of the application of criterion (ii) in relation to the post-1996 case studies is the first trend that focuses on the influences exerted by other properties on the heritage of the concerned historic town. The case studies that represent this trend are "Historic Jeddah, the Gate to Makkah", the "Historic Centre (Old Town) of Tallinn", and "Mdina (Citta' Vecchia)". For instance, the justifications of the OUV based on criterion (ii) of the "Historic Centre (Old Town) of Tallinn" indicate that the urban structure of the historic center of Tallinn has evolved under the influences that originated in other earlier Hanseatic towns, such as Visby [33]. The findings indicated that in few other post-1996 case studies the influences exerted by other properties on the concerned historic town were later transferred to other relevant properties in a mutual and continuous influences process, which is represented by the second trend. The only case study that represents this secondary trend is the "Historic Centre (Old Town) of Tallinn". However, this mutual influence process does not necessarily represent a dominant trend of the post-1996 historic towns. The findings revealed another emerging trend of the application of criterion (ii) in relation to the post-1996 case studies. This new trend, which is the third trend, focuses on interchanges of human values in the form of interchanges of technical know-hows, building materials and techniques, traditions, and religious values. This interchange of human values was responsible for mutual influences exerted among the concerned historic towns and other properties. The major case studies that represent this new trend are "Historic Jeddah, the Gate to Makkah", and the "Historic Centre (Old Town) of Tallinn". The justifications of the OUV based on criterion (ii) of these two WHSs focus on the interchange of human values that involved these two properties and other relevant properties. The justifications of the OUV based on criterion (ii) of Historic Jeddah indicate that its cityscape is the result of an exchange of human values, technical know-how, and building materials and techniques that took place across the Red Sea region and along the routes of the Indian Ocean [27]. The justifications of the OUV based on criterion (ii) of the other case study indicate that the historic town of Tallinn was a crucible that contributed to the development of an international culture through an interchange of traditions and religious values including the traditions of the Hanseatic League [28].

The findings revealed another secondary trend of the application of criterion (ii) in relation to the post-1996 case studies. This trend, which is the fourth trend, focuses on the integration of modern trends in architecture and town planning within the concerned historic town's design and planning as a form of mutual influences, and seeks the influences exerted by modern architectural and town planning theories instead of the influences exerted by other properties. The two case studies that represent this trend are "Le Havre, the City Rebuilt by Auguste Perret" and the "White City of Tel-Aviv-the Modern Movement". These two historic towns represent the modernism movement in architecture and town planning. Consequently, the justifications of their OUV based on criterion (ii) focus on the influences exerted by abstract theoretical themes of particular modern trends in architecture and town planning. For instance, the justifications of the OUV based on criterion (ii) of Le Havre indicate that the property is an outstanding example of the integration of urban planning traditions and the implementation of modern developments in architecture, technology and town planning [29].

The previous discussions revealed a clear shift in the application of criterion (ii) for the justification of historic towns' OUV following the amendment of its wording of 1996. After the amendment of 1996, the application of criterion (ii) changed from the focus on the influences exerted by the concerned historic towns on other relevant properties to the focus on the influences that the concerned historic towns underwent, and which were exerted by other relevant properties and in some cases the later transference of these influences to other properties in a mutual influences process. The previous conclusion indicates that the OUV of several historic towns could have never been justified based on criterion (ii) because these historic towns could have never been proven to represent major sources of 
influences and inspirations on developments in architecture or town planning. However, the OUV of these historic towns can be reconsidered after the amendment of the wording of criterion (ii). Rosetta in Egypt is an example of these historic towns. The cultural heritage in Rosetta is characterized by the several influences it underwent, and which were exerted by other cultures in northern Africa, and the later limited transference of these influences to create a new architectural style characteristic of the Delta region in Egypt.

Subsequently, the association between the application of criterion (ii) and the application of criterion (i), to justify the OUV of the pre-1996 and the post-1996 case studies, was explored. The exploration provided an explanation for the change in the application of criterion (ii), in relation to historic towns, following the amendment of its wording of 1996. In relation to the pre-1996 case studies, the findings revealed a significant association between the application of criterion (ii) and the application of criterion (i). The OUV of four of the pre-1996 case studies is justified based on both criteria (ii) and (i). These case studies are "Medina of Marrakesh", "Kairouan", "Historic Centre of Cordoba", and "Historic City of Toledo". On the other hand, the OUV of the other two pre-1996 case studies are justified based on criterion (ii) and other criteria that do not involve criterion (i). In relation to the post-1996 case studies, the findings revealed a clear disassociation between the application of criterion (ii) and the application of criterion (i). The OUV of only one of the post-1996 case studies is justified based on both criteria (ii) and (i). This case study is "Mdina (Citta' Vecchia)". On the other hand, the OUV of the other four post-1996 case studies is justified based on criterion (ii) and other criteria that do not involve criterion (i).

The previous finding emphasizes the existence of a significant association between the application of criterion (ii) and the application of criterion (i) to justify the OUV of the pre-1996 case studies, and the decline of this association in relation to the post-1996 case studies. This finding implies that many historic towns that were considered to enjoy an OUV prior to the amendment of 1996 because of the influences they exerted on other properties were also considered masterpieces of human creative genius. The previous argument is reasonable since those historic towns that are considered masterpieces of human creative genius should normally be regarded as role models that inspire the evolution of other similar properties. However, the amendment carried out to criterion (ii) implies that historic towns can be considered to enjoy an OUV because of the mutual influences they experienced, and that those historic towns are expected to have been influenced during their evolution by other properties. These mutual influences imply that those historic towns are not necessarily role models or masterpieces of human creative genius.

The findings revealed that some WHSs that exerted considerable influences on some of the case studies have not been inscribed on the WHL based on criterion (ii). "Historic Cairo" in Egypt is one of the sources that exerted some influences on the cultural heritage of "Historic Jeddah, the Gate to Makkah" [27]. Nevertheless, the criteria that have been adopted to justify Historic Cairo's OUV excluded criterion (ii). On the other hand, the traditional urban pattern of the "Historic Centre (Old Town) of Tallinn", another case study, was influenced by other major Hanseatic cities, particularly the "Hanseatic Town of Visby" in Sweden [33]. Although Visby has had profound influences on the evolution of Tallinn's traditional urban pattern, criterion (ii) has not been adopted to justify the OUV of the WHS in Visby [34].

\subsection{Major Aspects of Rosetta's Heritage that Represent the Interchange of Human Values}

Rosetta is situated to the north of Egypt on the western bank of the Nile's branch, known as the Rosetta branch, and very close to the Mediterranean. Rosetta retains a large number of medieval Islamic residences, most of which belong to the Ottoman era, such as Manzil 'Arab Kulli, and a large number of medieval mosques, such as the Mosque of Zaghlul. The city retains other medieval buildings, such as 
the Mill of Waqf al-Mahalli and the Gate of Abu ar-Rish. Rosetta also retains most of its historic street pattern almost intact. The two major old streets in the historic quarter are Zaghlul Street and Dehliz al-Mulk Street [35,36]. "Historic quarters and monuments of Rosetta/Rachid" is an Egyptian potential WHS. The property has been listed on Egypt's Tentative List in 2003. Criteria (ii), (iv) and (v) have been adopted to justify the property's OUV [5].

Rosetta's cultural heritage is characterized by the diverse influences it underwent, and which were exerted by other cultures in northern Africa, and the later limited transference of these influences throughout the Delta region in Egypt. This process of mutual influences took place through interchanges of human values. The major architectural paradigms that represent the mutual influences experienced throughout Rosetta's wider cultural context and the interchanges of human values are the ceramic tiles of Rosetta's historic buildings, the minarets of the mosques in Rosetta and their unique design, and the mushrabiyas used in Rosetta's houses. The most outstanding examples of historic buildings in Rosetta that retain ceramic tiles involve Manzil al-Qanadili, built in the first half of the 18th century [36], the Mosque of Salih Agha Dumaqsis, built in 1702 [36], Manzil 'Ilwan, built in the 19th century [36], and Manzil 'Abd al-Hamid Maharim, built in the 18th century [36]. These four historic buildings were built during the Ottoman dynasty [36]. Three distinctive design patterns characterize the ceramic tiles used in these buildings; which are the organic pattern, characterized by its floral ornaments; the geometrical pattern, and the plain pattern. All these buildings are characterized by their integration of the two major patterns, the organic and the geometrical patterns. Only two of these buildings retain ceramic tiles representing the third pattern, the plain tiles pattern, which are Manzil 'Ilwan and the Mosque of Salih Agha Dumaqsis. The ornaments of the ceramic tiles used in these four buildings bear a clear resemblance to the ornaments of the ceramic tiles used in the Mosque of Terbana in Alexandria. The Mosque of Terbana was constructed in 1685 during the Ottoman dynasty [37]. Both the Mosque of Terbana and the other historic buildings in Rosetta contribute to the establishment of a distinctive architectural style that is referred to as the Delta Architectural Style. The ceramic tiles used in the mosque in Alexandria are characterized by their integration of both patterns of ceramic tiles, which are the organic pattern that is rich of its floral ornaments and the geometrical pattern (Figure 1). The geometrical ornaments of the ceramic tiles used in the mosque in Alexandria are similar to those used in one of the historic buildings in Rosetta, which is Manzil 'Ilwan (Figure 1).

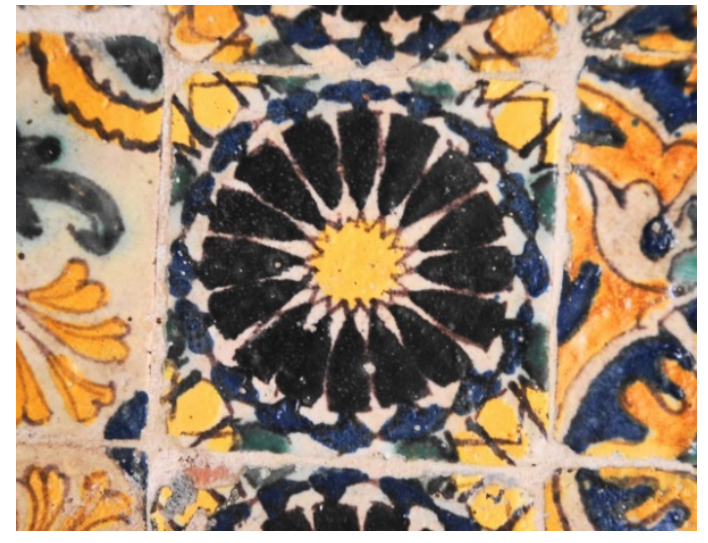

(a)

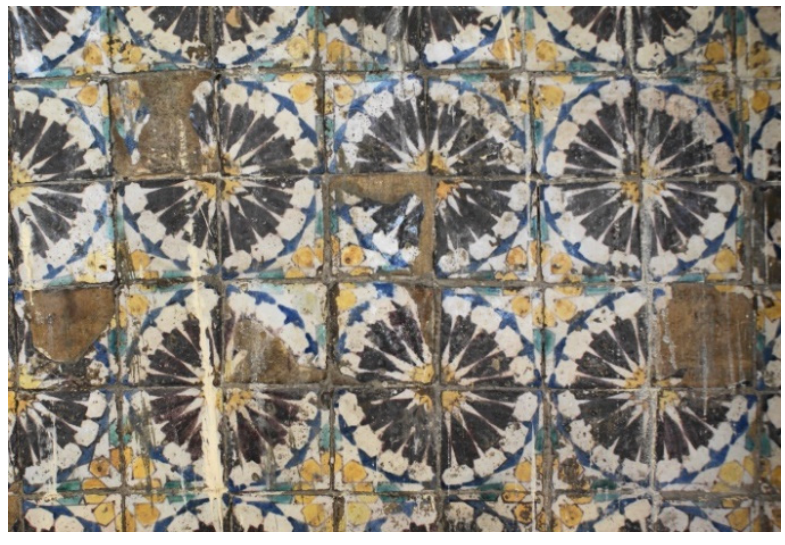

(b)

Figure 1. The photographs show the clear resemblance between the ornaments of the ceramic tiles used in Rosetta's historic buildings and the ornaments of the ceramic tiles used in the Mosque of Terbana in Alexandria, which was built in 1685 [37]: (a) A detailed photograph that shows one of the ceramic tiles that are used inside Manzil 'Ilwan in Rosetta, built in the 19th century [36], which are characterized by their geometrical pattern; (b) A photograph that shows some of the ceramic tiles that are used in the Mosque of Terbana in Alexandria, which are characterized by their geometrical pattern. 
The ornaments of the ceramic tiles used in the historic buildings in Rosetta bear a limited resemblance to those of the ceramic tiles used in other historic building in Historic Cairo, which belong to the Ottoman dynasty in Egypt. Among the most outstanding examples of historic buildings in Historic Cairo that represent the early Turkish influences on the ornaments of the historic ceramic tiles in Egypt are Bayt al-Sihaymi, built in 1648-1796 [38], Sabil-Kuttab of Abd al-Rahman Katkhuda, built in 1744 [38] (Figure 2), and the Mosque of Aqsunqur. Regarding that the Mosque of Aqsunqur was built in 1346 [38], therefore it belongs to the Bahri Mamluks dynasty. Nevertheless, the ceramic tiles were added to the mosque during the renovations carried out in 1652 [38]. Almost all the ceramic tiles used in these three historic buildings are characterized by their organic pattern and floral ornaments. Among the most outstanding examples of historic buildings in Turkey where similar ceramic tiles are used, which emphasize the Turkish profound influences on the ceramic tiles used in the Egyptian historic buildings that belong to the Ottoman dynasty in Cairo, is the Mosque of Sultanahmet in Istanbul, built in 1609-1617 [39]. The ceramic tiles that are used inside the mosque are characterized by the distinctive organic patterns and floral ornaments they bear. However, the Turkish distinctive style of historic ceramic tiles has had limited influences on the ornaments of the ceramic tiles in Rosetta's historic buildings. Some historic buildings in Rosetta retain small areas of ceramic tiles that bear organic patterns and floral ornaments in blue and white colors that represent these limited influences. The most outstanding examples of historic buildings in Rosetta that represent these influences are Manzil al-Mayzuni, built in 1740 [36], Manzil al-Qanadili, built in the first half of the 18th century [36], the Mosque of Salih Agha Dumaqsis, built in 1702 [36], and Manzil 'Abd al-Hamid Maharim, built in the 18th century [36] (Figure 2).

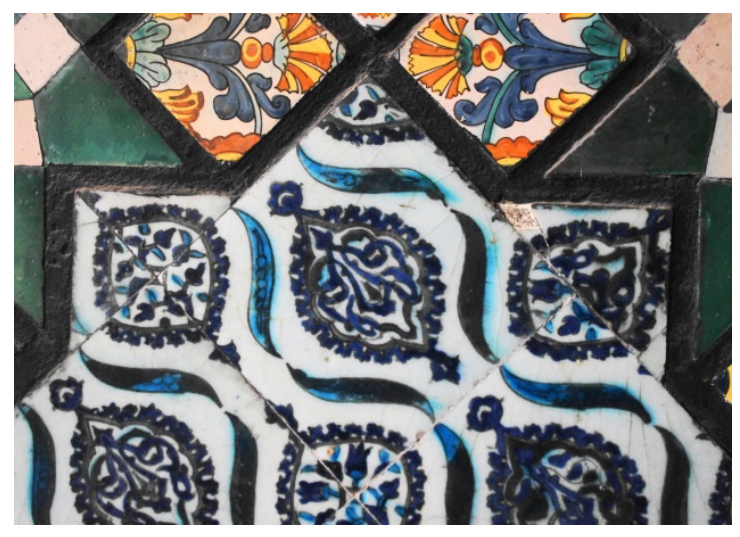

(a)

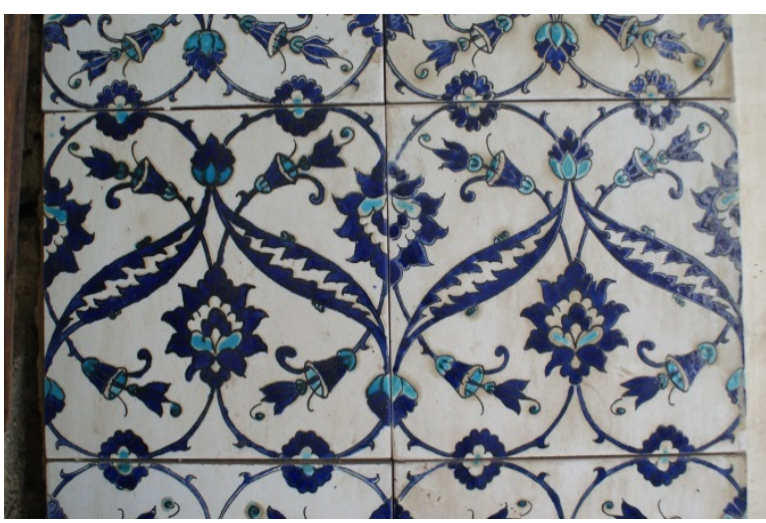

(b)

Figure 2. Two examples that illustrate the limited resemblance between the ornaments of some of the ceramic tiles used in Rosetta's historic buildings and the ornaments of the ceramic tiles used in other historic buildings in Historic Cairo that belong to the Ottoman dynasty in Egypt: (a) A detailed photograph that shows one of the few ceramic tiles that are used inside Manzil 'Abd al-Hamid Maharim in Rosetta, built in the 18th century [36], which are characterized by their organic pattern and the floral ornaments they bear, and which represent the limited Turkish influences on the ornaments of Rosetta's historic ceramic tiles; (b) An example of the ceramic tiles that are used inside Sabil-Kuttab of Abd al-Rahman Katkhuda in Historic Cairo, built in 1744 [38], which are characterized by the organic pattern and floral ornaments they bear. 
The ornaments of the ceramic tiles used in Rosetta's historic buildings bear a very clear resemblance to those of the ceramic tiles used in other historic buildings in Morocco and Spain. Among the most outstanding examples of historic buildings that retain similar ceramic tiles in Morocco is Madrasat al-Attarin in Fez, built in 1323-1325 [40], and among the most outstanding similar examples of historic buildings in Spain are the Palacios Nazaries in Granada, built from the mid-13th century to the late 14th century [41], and the Real Alcazar in Seville, built in 1364 [42]. The ornaments of the majority of the ceramic tiles that are used in Madrasat al-Attarin are characterized by the prevalence of the geometrical pattern. On the other hand, ceramic tiles are used inside the Palacios Nazaries in several places, such as the Sala de los Dos Hermanas, or the hall of the two sisters. The ornaments of the majority of the ceramic tiles used inside this hall are characterized by the prevalence of the geometrical pattern. Ceramic tiles are used inside the Real Alcazar mainly in the Patio de las Doncellas and its surrounding reception halls. The ornaments of the majority of these ceramic tiles are characterized by the prevalence of the geometrical pattern. The clear resemblance between the ceramic tiles used in the historic buildings in Morocco and Spain and those used in Rosetta indicate potential influences exerted by the historic buildings in Morocco and Spain. Several scholars [43-46] confirm this conclusion and emphasize the profound Moorish influences exerted on the ornaments of the historic ceramic tiles used in Rosetta's historic buildings. They all confirm that these influences are attributed to the immigration of many Moorish craftsmen to Egypt and their settlement in cities including Rosetta and Alexandria, and the ensuing interchange of their artistic know-how with their Egyptian counterparts.

The unique form of the minarets of Rosetta's mosques is another significant feature that represents the mutual influences experienced throughout Rosetta's wider cultural context. The form of the minarets' shafts of Rosetta's mosques bears a clear resemblance to the form of the minarets' shafts of other historic mosques in two nearby Egyptian cities, which are Alexandria and Fowah. Among the most outstanding examples of historic mosques in Rosetta whose minarets' form represents this resemblance are the Mosque of Salih Agha Dumaqsis, built in 1702 [36] (Figure 3) and the Mosque of Zaghlul, built in circa 1549 [36]. On the other hand, among the most outstanding examples of historic mosques in Alexandria whose minarets' form represents this resemblance is the Mosque of Terbana, built in 1685 [37] (Figure 3); whereas the most outstanding similar examples of historic mosques in Fowah are the Mosque of Hassan Nasr Allah, built in 1707 [43]; the Mosque of Abu al-Makarim, built in 1850 [43]; and the Mosque of al-Qinaai, built in 1720 [43]. The clear resemblance between the form of the minarets of the historic mosques in Rosetta and the form of minarets of similar mosques in Alexandria and Fowah indicates the likelihood of the existence of mutual influences experienced among Rosetta's historic mosques and the historic mosques in the other two cities. The geographical extent at which these mutual influences have been experienced is limited to the Delta region in Egypt.

The third architectural feature that represents the mutual influences experienced throughout Rosetta's wider cultural context is the form of the mushrabiyas used in some historic houses in Rosetta. The form of the mushrabiyas used in Rosetta's historic houses bears a clear resemblance to the form of the mushrabiyas used in other similar historic houses in Historic Cairo. Among the most outstanding examples of historic houses in Rosetta that retain mushrabiyas and represent this resemblance are Manzil Al-Hagg Isma'il Ramadan, built in the 18th century [36], and Manzil al-Tuqatli, built in the first half of the 18th century [36] (Figure 4); while the similar examples of historic houses in Historic Cairo involve, for instance, Bayt al-Sihaymi, built in 1648-1796 [38], and the House and Sabil of al-Kritliya, built in 1631 [38] (Figure 4). The resemblance between the form of the mushrabiyas used in the 
historic houses in Rosetta and the form of the mushrabiyas used in the historic houses in Historic Cairo indicates the high likelihood of the existence of mutual influences experienced by both cities, Rosetta and Cairo. The form of the mushrabiyas used in Rosetta's historic houses bears a considerable resemblance to the form of another similar architectural paradigm that was integrated in the traditional architecture in Valletta, Malta, which is known as the Maltese gallerija (Figure 4). The form of these galleriji was influenced by the mushrabiyas of northern Africa's traditional architecture, particularly in Morocco. The introduction of galleriji in Malta is attributed to early slavery practices that resulted in the enslavement of a large number of Turkish in Malta. Some of these slaves were master craftsmen who have participated in the introduction of galleriji in Malta, regarding that galleriji started to appear in Valletta during the mid-18th century [47]. The process through which galleriji were introduced in Malta represents an interchange of human values that took place through an exchange of the artistic know-how of the Turkish craftsmen with their Maltese counterparts. Therefore, the spread of mushrabiyas throughout Rosetta, northern Africa, and southern Europe can be attributed to broad international mutual influences and interchange of human values processes.

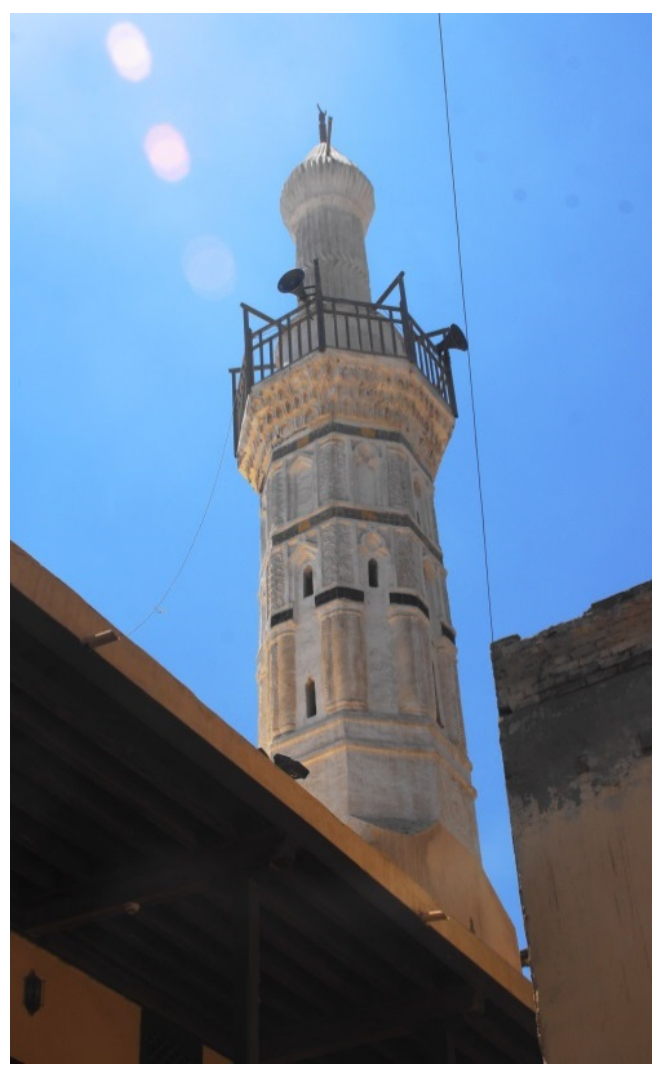

(a)

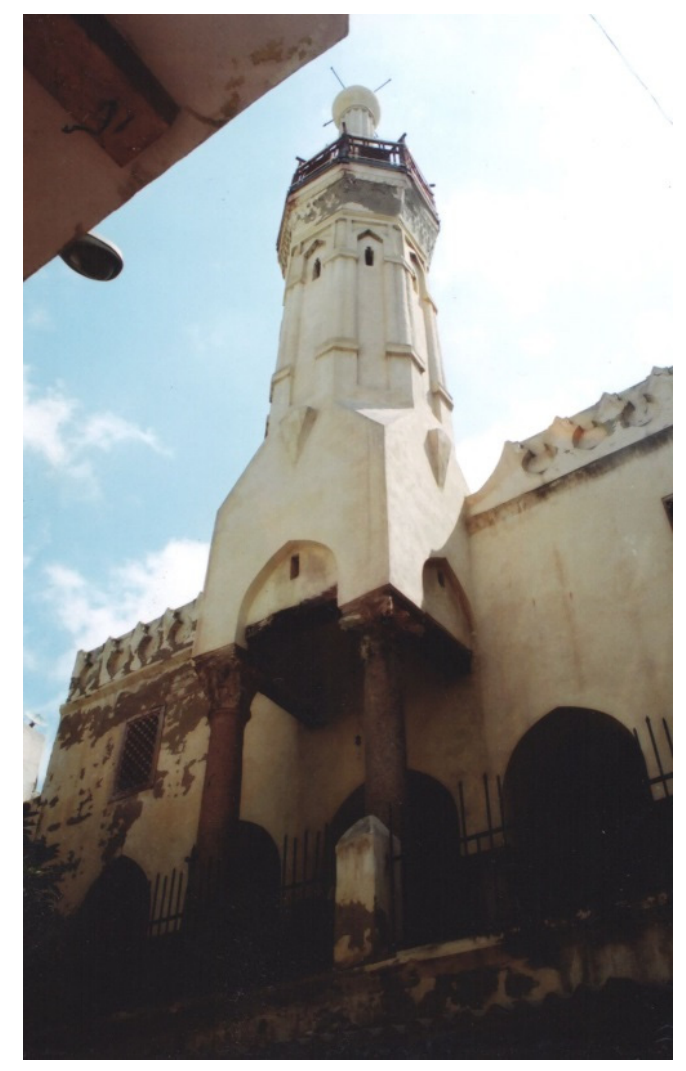

(b)

Figure 3. Two photographs that show the clear resemblance between the form of the minarets of Rosetta's historic mosques and the form of the minaret of one of the historic mosques in Alexandria, which is the Mosque of Terbana, built in 1685 [37]: (a) The minaret of the Mosque of Salih Agha Dumaqsis in Rosetta, built in 1702 [36]; (b) The minaret of the Mosque of Terbana in Alexandria. 


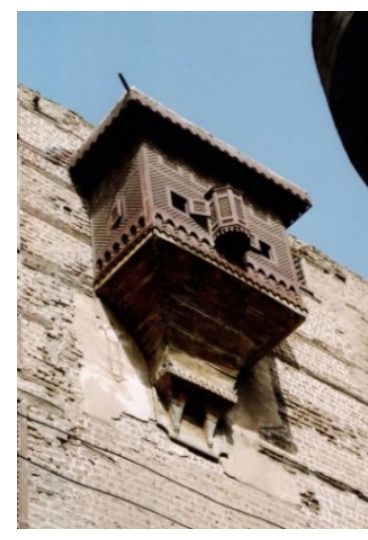

(a)

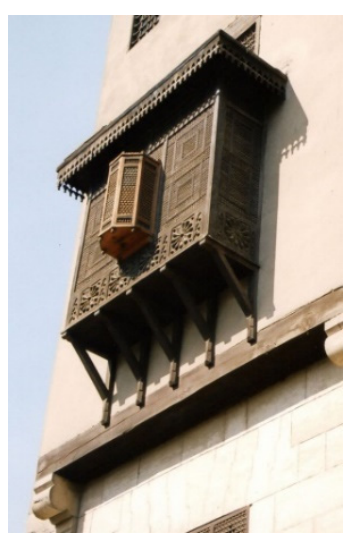

(b)

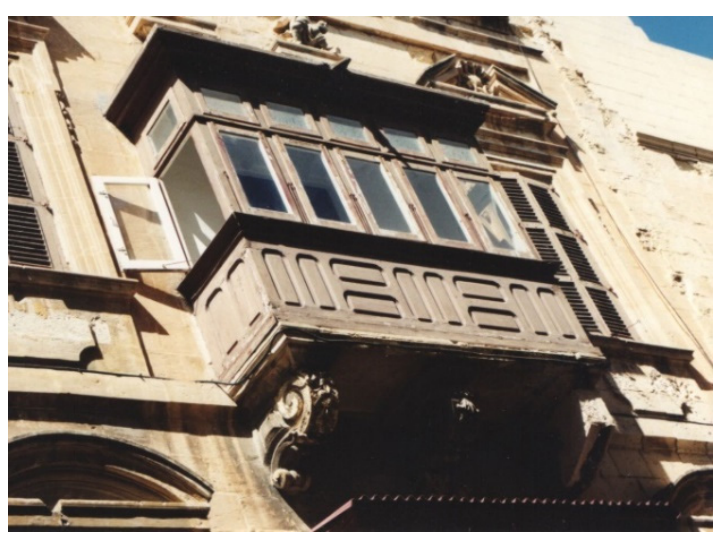

(c)

Figure 4. Three examples that show the clear resemblance between the form of the mushrabiyas used in Rosetta's historic houses and the form of the mushrabiyas used in the historic houses in Historic Cairo, and also shows the considerable resemblance with the form of the Maltese gallerija: (a) One of the timber mushrabiyas of Manzil al-Tuqatli in Rosetta, built in the first half of the 18th century [36]; (b) A photograph that shows an example of the mushrabiyas of the House and Sabil of al-Kritliya in Historic Cairo, built in 1631 [38]; (c) An example of the galleriji in Valletta, Malta, regarding that galleriji started to appear in Valletta during the mid-18th century [47].

\section{Conclusions}

The findings indicated that the amendment carried out to world heritage criterion (ii) in 1996 led to the emergence of a new trend to justify the OUV of historic towns. This new trend acknowledges the influences that the concerned historic town underwent and the later conveyance of these influences to other properties. These mutual influences usually take place through interchanges of human values represented by exchanges of artistic know-how, traditions, and religious values. This new trend is characterized by the decline of the association between criterion (ii) and criterion (i), which is concerned with the cultural properties representing masterpieces of human creative genius. The amendment carried out to criterion (ii) in 1996 is attributed to the then emerging interest in new types of cultural heritage, particularly vernacular and traditional living communities' heritage. Traditional communities' heritage is characterized by the diverse mutual influences these communities experienced through their encounter with other cultures. The emerging interest in traditional communities' heritage seems to have coincided with the emergence of a new perception of historic towns that acknowledges the mutual influences they experienced and the role that the interchange of human values played in their evolution.

The study emphasized the applicability of the revised version of criterion (ii) to the particularity of Rosetta's cultural heritage. Rosetta is characterized by the diverse influences its cultural heritage underwent, which were exerted by other cultures in northern Africa, and the later transference of these influences through the Delta region in an interchange of human values process. Several architectural paradigms represent the mutual influences that Rosetta experienced through interchanges of human values. The major paradigm that represents this interchange of human values is the ceramic tiles used in Rosetta's historic houses and mosques. The ornaments of Rosetta's ceramic tiles were influenced by two major trends, the first of which is the Moorish trend, while the other is the Turkish trend. 
The Moorish influences were introduced to Rosetta's architectural heritage by Moorish craftsmen who immigrated to Egypt and settled in a number of cities including Rosetta where they exchanged their artistic know-how with their Egyptian counterparts. The study recommends inscribing Rosetta on the WHL based on criterion (ii). The study suggests the revision of the nomination documents of other WHSs, which contributed to the mutual influences that Rosetta experienced, particularly Historic Cairo, in order to adopt criterion (ii) among the criteria that justify their OUV.

Funding: This research received no external funding.

Conflicts of Interest: The author declares no conflict of interest. The funders had no role in the design of the study; in the collection, analyses, or interpretation of data; in the writing of the manuscript, or in the decision to publish the results.

\section{References}

1. UNESCO. Basic Texts of the 1972 World Heritage Convention; United Nations Educational, Scientific and Cultural Organisation: Paris, France, 2005.

2. UNESCO World Heritage Centre. The Operational Guidelines of the World Heritage Convention; UNESCO World Heritage Centre: Paris, France, 1977.

3. UNESCO World Heritage Centre. The Operational Guidelines of the World Heritage Convention; UNESCO World Heritage Centre: Paris, France, 1996.

4. Abdel Tawab, A.G. Historic Towns of Outstanding Universal Value: Evaluating the Appropriateness of New Urban Development to Its Historic Context. In Proceedings of the 4th International Congress on Science and Technology for the Safeguard of Cultural Heritage in the Mediterranean Basin, Cairo, Egypt, 6-8 December 2009; Ferrari, A., Ed.; Grafica Elettrorica: Napoli, Italy, 2010; pp. 57-63.

5. Historic quarters and monuments of Rosetta/Rachid-UNESCO World Heritage Centre. Available online: https://whc.unesco.org/en/tentativelists/1831/ (accessed on 1 August 2018).

6. Bond, S.; Worthing, D. Managing Built Heritage, The Role of Cultural Values and Significance; John Wiley \& Sons Ltd.: Chichester, UK, 2010.

7. Australia ICOMOS Incorporated. THE BURRA CHARTER, The Australia ICOMOS Charter for Places of Cultural Significance; Australia ICOMOS Incorporated: Burwood, Australia, 2013.

8. Clark, K. Informed Conservation, Understanding Historic Buildings and Their Landscapes for Conservation; English Heritage: London, UK, 2001.

9. Aplin, G. Heritage, Identification, Conservation, and Management; Oxford University Press: South Melbourne, Australia, 2002.

10. Clark, K. Valuing Heritage, Creative Activities and Games for People Who Care about the Past, Manuscript in preparation.

11. Mason, R. Assessing Values in Conservation Planning: Methodological Issues and Choices. In Assessing the Values of Cultural Heritage; de la Torre, M., Ed.; The Getty Conservation Institute: Los Angeles, CA, USA, 2002; pp. 5-30.

12. UNESCO World Heritage Centre. The Operational Guidelines of the World Heritage Convention; UNESCO World Heritage Centre: Paris, France, 2017.

13. UNESCO World Heritage Centre. Information Document: Glossary of World Heritage Terms (Revised in October 1997); UNESCO World Heritage Centre: Paris, France, 1997.

14. Jokilehto, J. World Heritage: Defining the Outstanding Universal Value. City Time 2006, 2, 1-10.

15. Jokilehto, J. The World Heritage List, what is OUV? Defining the Outstanding Universal Value of Cultural World Heritage Properties; International Council on Monuments and Sites: Paris, France, 2008.

16. Abdel Tawab, A.G. Article 55 Directions: Developing and Revising Tentative Lists and their Potential Influences. In the Gotland Papers, Selected Papers from the VII International Conference on Easter Island and the Pacific, Migration, Identity, and Cultural Heritage, Proceedings of the VII International Conference on Easter Island and the Pacific; Migration, Identity and Cultural Heritage, Visby, Sweden, 20-25 August 2007; Wallin, P., Martinsson, H., Eds.; Gotland University Press: Visby, Sweden, 2010; pp. 511-530. 
17. Abdel Tawab, A. Evaluating the authenticity of traditional living communities' ever-evolving heritage. In HERITAGE 2016, 5th International Conference on Heritage and Sustainable Development, Proceedings of the 5th International Conference on Heritage and Sustainable Development, Lisbon, Portugal, 12-15 July 2016; Lira, S., Amoêda, R., Pinheiro, C., Eds.; Green Lines Institute for Sustainable Development: Barcelos, Portugal, 2016; pp. 1891-1901.

18. ICOMOS. World Heritage List No 313; International Council on Monuments and Sites: Paris, France, 1984.

19. ICOMOS. World Heritage List No 379; International Council on Monuments and Sites: Paris, France, 1985.

20. Medina of Fez-UNESCO World Heritage Centre. Available online: https://whc.unesco.org/en/list/170 (accessed on 1 August 2018).

21. Medina of Tunis-UNESCO World Heritage Centre. Available online: https://whc.unesco.org/en/list/36 (accessed on 1 August 2018).

22. Medina of Marrakesh-UNESCO World Heritage Centre. Available online: https://whc.unesco.org/en/list/331 (accessed on 1 August 2018).

23. Kairouan-UNESCO World Heritage Centre. Available online: https://whc.unesco.org/en/list/499 (accessed on 2 August 2018).

24. Historic Centre of Cordoba-UNESCO World Heritage Centre. Available online: https://whc.unesco.org/en/ list/313 (accessed on 5 August 2018).

25. Historic City of Toledo-UNESCO World Heritage Centre. Available online: https://whc.unesco.org/en/list/ 379 (accessed on 5 August 2018).

26. United Nations Educational Scientific and Cultural Organisation. Convention Concerning the Protection of the World Cultural and Natural Heritage, World Heritage List, Nomination Submitted by Tunisia, The Medina of Tunis; United Nations Educational Scientific and Cultural Organisation: Paris, France, 1978.

27. alGhabban, A. Historic Jeddah, the Gate to Makkah, Nomination Document for the Inscription on the World Heritage List; Saudi Commission for Tourism and Antiquities: Riyadh, Saudi Arabia, 2013.

28. Historic Centre (Old Town) of Tallinn-UNESCO World Heritage Centre. Available online: https://whc. unesco.org/en/list/822 (accessed on 1 August 2018).

29. Le Havre, the City Rebuilt by Auguste Perret-UNESCO World Heritage Centre. Available online: https://whc.unesco.org/en/list/1181 (accessed on 4 August 2018).

30. Historic Jeddah, the Gate to Makkah-UNESCO World Heritage Centre. Available online: https://whc. unesco.org/en/list/1361 (accessed on 1 August 2018).

31. Mdina (Citta' Vecchia)—UNESCO World Heritage Centre. Available online: https://whc.unesco.org/en/ tentativelists/983/ (accessed on 4 August 2018).

32. White City of Tel-Aviv—the Modern Movement-UNESCO World Heritage Centre. Available online: https://whc.unesco.org/en/list/1096 (accessed on 4 August 2018).

33. World Heritage Centre. World Heritage Convention, Nomination of Properties for Inclusion on the World Heritage List, Old Town Of Tallinn, Document C. 822; World Heritage Centre: Paris, France, 1996.

34. ICOMOS. World Heritage List, Visby, No 731; International Council on Monuments and Sites: Paris, France, 1995.

35. Abdel Tawab, A.G. Integrity and/or Authenticity: The Potential Challenges Facing the Nomination of Historic Towns for Inscription on the World Heritage List. In HERITY Italia, Measuring the Value of Material Cultural Heritage, Proceedings of the 2nd HERITY International Conference, Measuring the Value of Material Cultural Heritage, Rome, Italy, 3-5 December 2008; Quagliuolo, M., Ed.; DRI-Fondazione Enotria ONLUS: Rome, Italy, 2010; pp. 77-88.

36. Amin, N. The Historical Monuments of Egypt, Rosetta, Volume 1; Egyptian Antiquities Information System: Cairo, Egypt, 2008.

37. Bibliotheca Alexandrina. Cultural Routes of Alexandria; Bibliotheca Alexandrina: Alexandria, Egypt, 2006.

38. Warner, N. The Monuments of Historic Cairo; The American University in Cairo Press: Cairo, Egypt, 2005.

39. Sultanahmet Camii | Istanbul, Sultan Ahmed Camii, general view. "Constantinople, Mosquée de Sultan Ahmed" | Archnet. Available online: https://archnet.org/sites/2026/media_contents/62113 (accessed on 9 September 2018).

40. Madrasa al-'Attarin | Archnet. Available online: https://archnet.org/sites/1723 (accessed on 9 September 2018). 
41. Alhambra | Archnet. Available online: https://archnet.org/sites/2547 (accessed on 9 September 2018).

42. Alcázar of Seville | Archnet. Available online: https://archnet.org/sites/2852 (accessed on 9 September 2018).

43. Azab, K.M. Fowah, the City of Mosques, a Study on the City and its Religious and Civilian Architecture; Alahram Press: Cairo, Egypt, 1989. (In Arabic)

44. Al-Kadi, G.G.; Al-Sadik, M.T.; Ismail, M.H. Rosetta, Emergence, Prosperity and Decline; Dar Al-Afaq Al-Arabia: Cairo, Egypt, 1999. (In Arabic)

45. Al-Aaraj, A.M. Azulejos in Islamic Architecture in Algeria in the Turkish Era, an Archaeological and Artistic Study; Owayday Publications: Beirut, Lebanon, 1990. (In Arabic)

46. Khamess, K.H. Ceramic Tiles in the Ottoman Constructions in Lower Egypt, an Archaeological and Artistic Study. Master's Thesis, Cairo University, Cairo, Egypt, 2006. (In Arabic).

47. The Maltese Balcony-Maltese History \& Heritage. Available online: https://vassallohistory.wordpress.com/ the-maltese-balcony/ (accessed on 15 October 2018).

(C) 2019 by the author. Licensee MDPI, Basel, Switzerland. This article is an open access article distributed under the terms and conditions of the Creative Commons Attribution (CC BY) license (http://creativecommons.org/licenses/by/4.0/). 